Vol. 7, Nomor 2, Oktober 2013

\title{
Madrasah dan Ujian Nasional
}

\author{
Supa'at \\ Sekolah Tinggi Agama Islam Negeri Kudus \\ Email: supa'at@gmail.com
}

\begin{abstract}
This research analysis the implication of the policy of the national final exams (Ujian Nasional-UN) in basic to high school that conducts every year by the government, the ministry of education and culture. This researchnot discussabout the validity of UN as government policy, butthe main focus of this research is the implication of UN to madrasah as Islamic education institution that has unique and different character from general school. AsIslamic education,curriculum of madrasah based on the Islamic teachings which the sublime behavior as the final objective of Islamic education. In reality, the policy of UN has caused madrasah to become trapped in practical efforts to help student pass by focusing on repetitive practice of test in examination subject.The defication of test scores and the application of the policy standardization have result in the process education causing fear in students, teachers, and madrasah management. Finaly, students experient stress and depressiondue to fear of failing the UN.
\end{abstract}

Keywords: final exams (UN), UN policy implications, Islamic education, madrasah.

\begin{abstract}
Abstrak
Penelitian ini mengkaji implikasi dari kebijakan Ujian Nasional (UN) mulai dari Sekolah Dasar sampai Sekolah Menengah Atas yang dilakukan setiap tahun oleh Pemerintah, Kementrian Pendidikan dan Kebudayaan. Penelitian ini tidak membahas tentang keabsahan UN sebagai kebijakan pemerintah, tetapi fokus utama dari penelitian ini adalah implikasi dari UN untuk madrasah sebagai institusi pendidikan Islam yang memiliki Karakter yang unik dan berbeda dari sekolah umum. Sebagai pendidikan Islam, kurikulum madrasah didasarkan ajaran Islam yang luhur perilaku sebagai tujuan akhir pendidikan Islam. Pada kenyataannya, kebijakan UN telah menyebabkan madrasah menjadi terjebak dalam upaya praktis untuk membantu siswa lulus dengan berfokus pada praktek berulang tes dalam subjek pemeriksaan. Perolehan nilai ujian dan penerapan standarisasi kebijakan mengakibatkan rasa takut pada siswa, guru, dan manajemen madrasah. Akhirnya, siswa mendapati stres dan depresi karena takut gagal dalam UN.
\end{abstract}

Kata kunci: Ujian Nasional (UN), Implikasi Kebijakan Ujian Nasional, Pendidikan Islam, Madrasah.

ISSN 1979-1739

(C) 2013 Nadwa | IAIN Walisongo

http://journal.walisongo.ac.id/index.php/nadwa 


\section{A. Pendahuluan}

Secara kelembagaan, eksistensi madrasah sebagai lembaga pendidikan dalam konteks sistem pendidikan nasional telah mendapat status seperti yang diperjuangkan selama ini, yaitu sama dengan sekolah. Secara yuridis pengakuan tersebut tertuang dalam Undang-Undang Nomor 2 Tahun 1989danUndang-Undang Nomor 2 Tahun 1989 tentang Sistem Pendidikan Nasional. Pengakuan ini menjadi penting bagi madrasah, karena selama ini madrasah kurang mendapatkan perhatian yang sewajarnya dari pemerintah, bahkan pada dataran tertentu dipandang dengan sebelah mata dan diperlakukan secara diskriminatif. Hal ini terjadi karena madrasah lebih dipandang sebagai lembaga keagamaan (lembaga dakwah) ketimbang sebagai lembaga pendidikan. Sudut pandang ini juga dapat dimengerti dan dipahami karena madrasah selama ini menjadikan ilmu-ilmu agama (ulümuddin) sebagai tema sentral pembelajarannya, mata pelajaran umum hanya sebagai tambahan.

Konsekuensi dari pengakuan sama tersebut, kurikulum madrasah diperbaharui dengan kurikulum 1994 dengan perbandingan alokasi waktu antara 16-18\% untuk pelajaran agama dan antara $82-86 \%$ mata pelajaran umum, dengan catatan bahwa alokasi waktu mata pelajaran umum muatan nasional diberlakukan $100 \%$ sama dengan sekolah umum setingkat. ${ }^{1}$ Dengan kata lain, pengakuan dan status sama dengan sekolah umum ini madrasah harus tunduk dan mengikuti semua regulasi dan kebijakan yang diambil oleh Kementerian Pendidikan dan Kebudayaan. UN adalah salah satu contoh kebijakan pendidikan tersebut.

Meskipun kebijakan ini oleh sementara kalangan dipandang sebagai langkah maju, namun tidak semua kalangan menerima sepenuhnya, faktanya tidak semua madrasah pada saat itu patuh terhadap keputusan ini. Ketidakpatuhan sebagian madrasah ini lebih didasarkan atas kekhawatiran madrasah akan kehilangan jati dirinya sebagai lembaga pendidikan Islam, yaitu sebagai agen pencetak kader ulama. ${ }^{2}$ Dalam istilah Azyumardi Azra, madrasah dan pesantren akan menghadapi "krisis identitas", karena muatan

${ }^{1}$ Departemen Agama RI, Sejarah Madrasah, (Jakarta: Direktorat Jenderal Pendidikan Islam, 2004), hlm. 34.

${ }^{2}$ Suwito \& Fauzan, (Ed.), Perkembangan Pendidikan Islam di Nusantara: Studi Perkembangan Sejarah dari Abad 20 M. (Bandung, Angkasa, 2004), hlm.203. 
pelajaran umum yang begitu besar pada gilirannya dapat menghilangkan misi, substansi, dan Karakternya sebagai lembaga pendidikan Islam. ${ }^{3}$ Sementara bagi yang menerima berargumen bahwa kebijakan ini merupakan pengakuan yang lebih nyata terhadap eksistensi madrasah sekaligus langkah awal yang positif bagi proses pengintegrasian madrasah dalam sistem pendidikan nasional. Wacana "integrasi" tersebut muncul sebagai respons atas realitas dualisme pengelolaan pendidikan, yaitu antara Kementerian Pendidikan dan Kebudayaan dan Kementerian Agama. ${ }^{4}$

Kekhawatiran lain yang muncul terkait dengan status dan format kurikulum barunya ini adalah alumni madrasah tidak memperoleh keduanya baik pengetahuan umum maupun pengetahuan agama. Hal ini terjadi lebih disebabkan karena pengakuan legal formal tersebut tidak berbanding lurus dengan realitas obyektif di lapangan di mana madrasah menghadapi berbagai problem dan keterbatasan, baik infrastruktur pembelajaran maupun sumberdaya manusia. Menurunnya kualitas capaian/penguasaan ilmu-ilmu agama siswa madrasah lebih disebabkan karena keterbatasan alokasi waktu untuk pembelajaran sehingga sulit untuk mencapai kompetensi atau standar sebagaimana diharapkan.

UN sebagai sebuah kebijakan merupakan aplikasi dari UU No: 20 tahun 2003 tentang Sistem Pendidikan Nasional, khususnya pasal 57 ayat (1): Evaluasi dilakukan dalam rangka pengendalian mutu pendidikan secara nasional ...".Selanjutnya pada ayat (2) disebutkan: "Evaluasi dilakukan terhadap peserta didik, lembaga, dan program pendidikan pada jalur formal...". Kemudian, pasal 58 ayat (1) disebutkan: "Evaluasi hasil belajar peserta didik dilakukan oleh pendidik untuk...". Secara teoritik UN merupakan kegiatan pengukuran dan penilaian kompetensi peserta didik secara nasional pada jenjang pendidikan dasar dan menengah. Dari sudut kebijakan, tujuan diselenggarakan UN antara lain yaitu untuk mengukur pencapaian kompetensi lulusan peserta didik (siswa) secara nasional pada mata pelajaran tertentu dalam kelompok mata pelajaran ilmu pengetahuan dan teknologi serta untuk mempetakan tingkat pencapaian hasil belajar siswa pada tingkat sekolah dan daerah.

${ }^{3}$ Jajat Burhanudin \& Dina A., Eds.,Mencetak Muslim Modern: Peta Pendidikan Islam Indonesia, (Jakarta: Raja Grafindo Persada, 2006), hlm. 4.

${ }^{4}$ Departemen Agama RI, Sejarah Madrasah, 2004, hlm.145. 
UN yang pada awalnya merupakan satu-satunya alat yang digunakan untuk mengukur keberhasilan siswa dalam belajar di sekolah, karena berbagai kritik dan saran telah terjadi perubahan signifikan. Contoh, formula baru kelulusan siswa mulai tahun 2010 adalah menggabungkan nilai UN dengan nilai sekolah. Rumus yang ditawarkan pemerintah untuk nilai gabungan $=(0,6 \mathrm{x}$ nilai $\mathrm{UN})+(0,4 \mathrm{x}$ nilai sekolah). Nilai sekolah dihitung dari nilai rata-rata ujian sekolah dan nilai rapor semester 3-5 untuk tiap mata pelajaran UN. Adapun kriteria kelulusan ujian sekolah diserahkan kepada sekolah. Dengan perubahan ini seharusnya UN tidak lagi menghantui siswa/pihak terkait. Namun faktanya, ketegangan tetap mewarnai pada saat-saat menjelang pelaksanaan dan pengumuman hasil kelulusan. Hal ini karena masih dominannya hasil UN sebagai penentu kelulusan siswa.

Kebijakan baru yang memasukkan nilai sekolah menjadi bagian dari penentuan kelulusan bukan tanpa celah untuk disiasati oleh pihak yang hanya semata-mata mengejar Prestasi dalam meluluskan siswa sekolah. Pengkatrolan nilai sekolah untuk siswa mungkin saja dilakukan pihak sekolah yang menginginkan para siswa lulus sebanyak-banyaknya agar dianggap sebagai satu Prestasi sekolah. Nilai yang dikatrol bisa jadi berbeda dengan nilai hasil UN. Jika ini terjadi maka sangat mungkin akan tampak ketimpangan antara hasil sekolah dengan hasil UN yang seharusnya tidak boleh terjadi. Hal ini terjadi karena setiap materi tes yang baik dan teruji seharusnya akan menghasilkan nilai yang sama atau tidak jauh berbeda antara nilai sekolah dan nilai UN.

Dari sisi konsep dan teori pembelajaran, ujian yang berbentuk "paper and pencil test" (seperti UN) bukanlah segala-galanya, dalam arti bahwa ia tidak dapat mengukur semua aspek perolehan belajar para siswa. Tes tertulis hanya dapat mengukur aspek-aspek tertentu saja khususnya pada ranah kognitif. ${ }^{5}$ Oleh karenanya, secara akademik hasil UN seharusnya tidak boleh dijadikan penentu untuk kelulusan. Karena UN bukan suatu tes multifungsi yang cocok untuk semua (a test fits for all). Di samping fakta non kependidikan lainnya yang terjadi di lapangan, yaitu kecemasan yang melanda banyak pihak tidak hanya siswa, orang tua, guru dan kepala sekolah tetapi juga pimpinan daerah. Fakta lain yang tidak kalah pentingnya adalah, hasil UN tidak jarang dijadikan sebagai

${ }^{5}$ Nana Sudjana, Penilaian Hasil Proses Belajar Mengajar, (Bandung: Remaja Rosdakarya, 1995), hlm. 15. 
prestise/gengsi sekolah dan martabat daerah. Tidak hanya guru dan Kepala Sekolah tapi pimpinan/birokrat daerah pun ikut "mengatur cara" agar sekolah-sekolah di wilayahnya sukses dalam meluluskan siswa dengan hasil yang maksimal.

Kebijakan dalam pendidikan, dalam istilah House dan Mathison disebut dengan social intervention in education, tujuannya adalah untuk perubahan dan perbaikan. ${ }^{6}$ Harrington menyebutnya dengan istilah improvement process. ${ }^{7}$ Meskipun improvement itu akan mengakibatkan perubahan, namun "perubahan" tidak harus diasumsikan akan membawa perbaikan. Tidak jarang suatu perubahan sebagai"hasil"kebijakan tidak mampu menyentuh aspek substantifdari objek kebijakan tapi hanya menyentuh permukaan atau sekadar formalitas. Oleh karenanya, menurut Hopkins, dalam konteks pendidikan improvement diartikan sebagai " $a$ distinct approach to educational change that enhances student outcomes as well as strengthening the school's capacity for managing chan$g e^{\prime \prime}$.

Di samping memiliki Karakteristik khusus, keberhasilan suatu kebijakan dalam pendidikan tidaklah berdiri sendiri tetapi banyak faktor yang terlibat, mempengaruhi dan bahkan menentukan. Tidak hanya faktor internal tetapi juga berbagai faktor eksternal pendidikan. Oleh karenanya tidak jarang suatu kebijakan yang didesain untuk menghasilkan perubahan, hanya berhenti sebatas kebijakan itu sendiri tanpa mampu menghasilkan perubahan sebagaimana diinginkan. Seperti dikatakan oleh Fullan, "the purpose of educational change presumably is to help school accomplish their goals more effectively by replacing some structures, program and/or practice with the better ones". 9

Terimplementasi atau tidaknya suatu kebijaksanaan, berhasil tidaknya implementasi kebijaksanaan, ditentukan oleh banyak faktor. Menurut Ali Imron, ada enam faktor yang mempengaruhi im-

${ }^{6}$ Seidman, E., Handbook of social intervention. (Beverly Hill/London/ New Delhi: Sage Publication, 1983), hlm.323.

${ }^{7}$ Harrington, H. J, The improvement process: How America's Leading Company Improve Quality, (New York: Mc Graw Hill Book Company, 1987), hlm. xiii.

${ }^{8}$ Hopkins, D., Every School a Great School: Realizing the Potential of System Leadership, (New York: Mc Graw Hill-Open University Press, 2006), hlm.ix.

${ }^{9}$ Fullan, M. G. The New Meaning of Educational Change, (England: Cassell Educational Limited, 1991), hlm.15. 
plementasi suatu kebijakan: (1)Kompleksitas berbagai kebijakan yang telah dibuat; 2) Ketidakjelasan rumusan masalah kebijakan dan alternatif pemecahan masalah kebijakan; 3) Ketersediaan sumber-sumber potensial yang dapat mendukung pelaksanaan kebijakan; 4) Kemampuan dan keahlian pelaksana kebijakan; 5) Dukungan dari khalayak sasaran kebijakan; 6) Efektivitas dan efisiensi birokrasi. ${ }^{10}$

Penelitian ini tidak membahas validitas UN sebagai sebuah kebijakan, namun lebih difokuskan pada realitas pelaksanaan UN terutama pada lembaga pendidikan madrasah. Secara spesifik penelitian ini akan membahas pengaruh $\mathrm{UN}$ pada madrasah di $\mathrm{Ku}-$ dus, khususnya Madrasah Aliyah. Secara metodologis penelitian ini menggunakan pendekatan kualitatif-fenomenologis dengan teknik pengumpulan data: observasi partisipatori, indepth interview, kajian dokumen.

\section{B. Ujian Nasional}

Seperti telah disinggung di atas Ujian Nasional (UN) adalah kebijaan kependidikan yang diambil oleh pemerintah, secara umum tujuannya adalah untuk mengevaluasi kinerja pendidikan (dasar dan menengah) secara nasional. Dengan evaluasi sebuah kegiatan akan diketahui keberhasilan atau bahkan kegagalanya. Secara teoritik, evaluasi adalah sebuah aktivitas mengumpulkan informasi dan membandingkan antara tujuan yang telah ditetapkan dengan hasil yang telah dicapai. Untuk memberi gambaran lebih luas tentang evaluasi,berikut dipaparkan beberapa definisi evaluasi yang dirumuskan oleh para ahli, antara lain: (1) One prominent, long-standing definition states that evaluation involves comparing objectives and outcomes... ${ }^{11}(2)$ Evaluation is the systematic assessment/investigationof the worth or merit of same object. ${ }^{12}(3)$ Evaluation is the process of determinis to what extened the Educational objectives are actually being realized. ${ }^{13}(4)$ Evaluation

${ }^{10}$ Ali Imron, Kebijakan Pendidikan di Indonesia: Proses Produk dan Masa Depannya. (Jakarta: Bumi Aksara, 1996). hlm.76-77.

${ }^{11}$ Stuflebeam D.L. et al., Educational Evaluation and Decesion Making. (Itasca, IL: Peacock, 1971, hlm.3.

${ }^{12}$ Stuflebeam, Educational Evaluation ..., hlm. 3.

13 Tyler, R.W., Basic Principle of Curriculum and Instruction. (IL. University of Chicago Press, 1950), hlm. 69. 
is providinginformation for decision making. ${ }^{14}(5)$ Evaluation is the comparison of performance to same standards to determine whether discrepancies existed. ${ }^{15}$

Menurut Anas Sudjiono, ruang lingkup evaluasi meliputi tiga aspek, yaitu: 1) evaluasi mengenai program pengajaran; 2) evaluasi mengenai proses pengajaran; 3) evaluasi mengenai hasil belajar (hasil pengajaran). ${ }^{16}$ Dengan demikian, secara umum evaluasi pembelajaran bertujuan untuk mengumpulkan informasi terkait dengan proses pembelajaran yang telah dilakukan untuk menentukan tingkat capaian/hasil pembelajaran yang telah dilakukan. Karena tidak mungkin bisa diketahui Prestasi belajar siswa jika di akhir program belajar tidak dilakukan evaluasi dengan mengukur (pengukuran) dan menilai (penilaian). Pengukuran pada dasarnya adalah kegiatan penentuan angka untuk menggambarkan Karakteristik suatu obyek. Dalam konteks UN, akan menghasilkan angka (nilai) yang bermanfaat untuk memperoleh, menganalisis, dan menafsirkan data tentang proses dan hasil belajar siswa. Data tersebut dapat menjadi informasi yang bermakna dalam pengambilan keputusan untuk program pendidikan selanjutnya.

Penilaian dalam dunia pendidikan tujuan dasarnya, antara lain: 1) menentukan tingkat ketercapaian kemampuan dasar; 2) mengetahui pertumbuhan dan perkembangan kemampuan siswa; 3) mendiagnosis kesulitan belajar siswa; 4) meningkatkan motivasi belajar; 5) mendorong guru untuk mengajar lebih baik; 6) memberikan informasi kepada orang tua dan masyarakat sebagai bentuk akuntabilitas lembaga pendidikan. ${ }^{17}$

Sebagaimana dijelaskan dalam Keputusan Menteri PendidikanNasional Nomor 153/2003; tujuan penyelenggaraan UAN (UN) adalah untuk; 1) mengukur pencapaian hasil peserta didik; 2) mengukur mutu pendidikan di tingkat nasional, provinsi, kabupaten/kota, dan sekolah/madrasah; 3) pertanggungjawaban penyelenggaraan pendidikan secara nasional, provinsi, kabupaten/kota, sekolah/madrasah, kepada masyarakat. Sedangkan

${ }^{14}$ Cronbach, L.J., Course Improvement Trough Evaluation. (Teacher College Record, 1963), hlm.64.

${ }^{15}$ Stuflebeam, Educational Evaluation ...,hlm.7.

${ }^{16}$ Anas Sudjiono, Pengantar Evaluasi Pendidikan. (Jakarta: Rajawali Pers, 2001), hlm. 29.

${ }^{17}$ Djemari Mardapi, Penyusunan Tes Hasil Belajar, (Yogyakarta: Program Pasca Sarjana Universitas Negeri Yogyakarta, 2004), hlm.13-19. 
fungsi UN adalah: 1) alat pengendali mutu pendidikan secara nasional; 2) pendorong peningkatan mutu pendidikan; 3) bahan dalam menentukan kelulusan peserta didik; 4) bahan pertimbangan dalam seleksi penerimaan peserta didik pada jenjang yang lebih tinggi.

UN yang dilaksanakan saat ini sesungguhnya merupakan modifikasi atau penyempurnaan model yang selama ini sudah ada,meskipun nama dan sistemnya berbeda atau berubah. Satu hal yang sama adalah sistem ini bertujuan untuk mengetahui hasil belajar dan pembelajaran yang telah dilakukan. Untuk mengetahui perkembangan UN di Indonesia, berikut dijelaskan sekilas tentang perkembangan $\mathrm{UN}$ :

1. Tahun 1965-1971, sistemnya bernama Ujian Negara. Berlaku hampir di semua mata pelajaran, semua jenjang pendidikan yang ada di Indonesia, satu komando dan satu kebijakan pemerintah pusat.

2. Tahun 1972-1979, sistemnya bernama Ujian Sekolah. Jadi sekolah yang menyelenggarakan ujian sendiri-sendiri. Semuanya diserahkan kepada sekolah, pemerintah pusat hanya membuat kebijakan-kebijakan umum terkait dengan ujian yang dilaksanakan.

3. Tahun 1980-2000, sistemnya bernama Evaluasi Belajar Tahap Akhir Nasional (EBTANAS). Dalam ujian ini, dikembangkan perangkat ujian paralel untuk setiap mata pelajaran yang diujikan. Sedangkan terkait dengan penggandaan dan monitoring soal dilaksanakan oleh daerah masing-masing.

4. Tahun 2001-2004, Sistemnya bernama Ujian Akhir Nasional (UNAS). Hal yang berbeda dari UNAS adalah penentuan kelulusan siswa. Dalam EBTANAS kelulusannya berdasarkan nilai dua (2) semester rapor terakhir dan nilai EBTANAS murni, sedangkan UNAS ditentukan pada mata pelajaran secara individual.

5. Tahun 2005-2009, sistemnya tetap bernama UNAS dengan perubanan sistem yaitu pada target wajib belajar pendidikan (SD/MI/SD-LB/MTs/SMP/SMP-LB/SMA/MA/SMK/SMALB) sehingga nilai kelulusan ada target minimal.

6. Tahun 2010-Sekarang, sistemnya bernama Ujian Nasional (UN). Untuk UN tahun 2012, ada ujian susulan bagi siswa yang tidak lulus UN. Dengan target, para siswa yang ujian 
dapat mencapai nilai standar minimal UN sehingga dapat lulus UN dengan baik.

Sampai tahun 1990, UN/EBTANAS hanya diikuti oleh lembaga pendidikan (sekolah) di bawah naungan Kementerian Pendidikan dan Kebudayaan, dengan demikian madrasah tidak mengikuti program tersebut. Baru pada tahun 1990-an, madrasah mulai mengikuti program EBTANAS. Meskipun demikian, baik di sekolah umum ataupun madrasah tidak mengikutkan bidang studi agama (PAI) sebagai mata pelajaran yang dievaluasi/diujikan tersebut. Selain mengikuti ujian nasional, dengan jumlah mata pelajaran yang sama seperti yang diujikan kepada siswa SMA, untuk siswa MA harus mengikuti Ujian Akhir Madrasah Berstandar Nasional (UAMBN), yakni berupa mata pelajaran yang tergabung dalam rumpun PAI yang meliputi mata pelajaran: Quran-Hadis, Aqidah Akhlak, Fiqh, Sejarah Kebudayaan Islam, Bahasa Arab. Ujian ini biasanya dilaksanakan selama tiga hari. Di samping UN dan UAMBN masih ada lagi jenis ujian akhir,yaitu Ujian Madrasah. Mata pelajaran yang diujikan adalahmata pelajaran agama Islam yang terangkum dalam Kurikulum Lokal sesuai visi-misi masing-masing madrasah, khususnya madrasah swasta.

Secara spesifik tujuan UAMBN adalah untuk mengukur capaian hasil belajar peserta didik di akhir jenjang pada satuan pendidikan sesuai dengan standard kompetensi lulusan yang ditetapkan secara nasional. Hasil UAMBN juga sebagai bahan dalam pemetaan dan umpan balik untuk perbaikan program pembelajaran PAI dan bahasa Arab pada madrasah. Secara teknis pelaksanaan ujian ini mengadopsi sistem yang ada pada $\mathrm{UN}$, dan soal ujiannya juga ditetapkan oleh pemerintah pusat.

Tidak diujikannya bidang studi agama (PAI) dalam UN tetap menjadi pertanyaan besar hingga kini. Bangsa Indonesia yang dikenal dengan bangsa yang agamis ini pada kenyataannya dalam sistem pendidikannya, pendidikan agama tidak termasuk bidang studi yang diujikan dalam sistem evaluasi akhirnya. Meskipun mata pelajaran agama, sesuai UU No: 2 tahun 1989 maupun UU No: 20 Tahun 2003, wajib diberikan pada semua jenjang pendidikan mulai sekolah dasar sampai perguruan tinggi. Bagaimana nanti, jika standar kelulusan sekolah tak sedikitpun mencerminkan Pendidikan Agama bagi bangsa. Lalu, nilai dan norma dasar apa 
yang dipakai untuk membangun bangsa ini kalau tak ada dasardasar agama tersebut.

Dengan tidak mengikutkan bidang studi agama dalam UN, secara tidak langsung standar kelulusan tak ada nilai moral/akhlaknya. Hal ini sangat bertentangan dengan tujuan pendidikan yang ingin dicapai, sebagaimana dirumuskan dalam tujuan pendidikan nasional, antara lain adalah berimanan dan bertaqwa. Dengan begini kemampuan manusia hanya diukur dengan deret angka, jauh dari realitas atau bahkan tak mewakili sama sekali. Langsung atau tidak pendidikan telah tidak mampu mencerdaskan lagi secara spiritual. Bahkan menjadikan peserta didik menjadi menjadi robot, karena mengukur kemampuan manusia hanya sebatas dengan ukuran nominal. Semua itu telah membuat degradasi nilai-nilai pendidikan dan sangat bertentangan dengan konstitusi negara.

Dengan tidak mengikutkan pendidikan agama sebagai mata pelajaran yang di-UN-kan, berdampak pada perlakuan anak didik terhadap mata pelajaran agama menjadi berbeda. Mereka menganggap sepele terhadap mata pelajaran agama dan cenderung apatis dengan kegiatan-kegiatan simbol-simbol yang berbau agama. Padahal dalam kehidupan sehari-hari mereka pasti bersinggungan dengan nilai-nilai tersebut. Hasilnya pendidikan tak lagi membangun manusia secara utuh. Namun, hanya mengoptimalkan intelegensi yang diharapakan oleh pasar tanpa punya rasa kemanusiaan. Fenomena tawuran dan prilaku dekadensi lainya menjadi bukti akan keringnya manusia Indonesia dari norma dan nilai agama.

\section{Ujian Nasional untuk Madrasah}

Secara umum, tidak terkecuali madrasah, pelaksanaan UN telah membuat lembaga pendidikan kita kalang kabut dan terperosok dalam lubang hitam disorientasi pendidikan. Madrasah sebagai lembaga pendidikan yang mengemban dua misi sekaligustransformasi pengetahuan umum dan pengetahuan agama Islamjuga mengalami hal yang sama. Keadaan ini menjadi semakin berat karena madrasah memikul beban tambahan yaitu membentuk pribadi-pribadi yang berwawasan luas dan berakhlakul karimah.

Data dan pembahasan tentang UN dalam tulisan ini tidak dalam konteks membahas setuju atau tidak setuju berbagai hal yang terkait dengan pelaksanaan UN untuk MA, tetapi lebih difokuskan pada pengaruh implementasi kebijakan UN tersebut 
terhadap eksistensi dan jati diri MA sebagai Sekolah Menengah Umum berciri khas agama Islam. Dalam pandangan penulis kebijakan UN yang juga diberlakukan untuk MA adalah kebijakan wajib yang tidak bisa ditolak sebagai konsekuensi menyatunya sistem pendidikan madrasah dalam sistem pendidikan nasional, apapun yang terjadi dan apapun hasilnya semua MA harus tunduk dan mengikuti kebijakan tersebut.

Seperti diketahui perdebatan tentang UN sudah terjadi sejak digulirkannya kebijakan tersebut pada tahun ajaran 2002/2003 yang pada awalnya bernama EBTANAS dan UAN. Oleh karenanya membahas setuju atau tidak setuju pelaksanaan UN untuk MA dalam tulisan ini tidak memiliki signifikansi dengan tema penelitian ini. Data yang dikumpulkan terkait pelaksanaan UN untuk MA di sini difokuskan pada bagaimana pengaruh kebijakan tersebut pada implementasi MA sebagai sekolah menengah umum berciri khas Islam.

Kebijakan UN sebagai salah satu upaya untuk menjamin kualitas proses dan hasil pendidikan semua pihak di MA sepakat, karena tidak mungkin kualitas pendidikan akan tercapai manakala tidak ada standar yang jelas sebagaitolok ukur norma dan acuan. Namun persoalannya adalah standar yang ditetapkan saat ini lebih pada hasil bukan proses, sehingga yang terjadi standar yang ditetapkan berubah menjadi penyeragaman realitas yang sebenarnya beragam baik input maupun prosesnya. Ketika UN yang berorientasi pada hasil tersebut diterapkan pada seluruh lembaga pendidikan sesuai tingkatannya tanpa mempertimbangkan realitas obyektif pada skala mikro sekolah/madrasah, di situlah kemudian berbagai persoalan muncul. Mana mungkin akan diperoleh hasil yang obyektif manakala standar dan alat ukur yang digunakan sama untuk mengukur obyek yang berbeda. Mulai dari perbedaan negeri-swasta, sekolah-madrasah, wilayah pedesaan-perkotaan, sekolah madrasah maju-sedang-tidak maju (dengan indikator skor akreditasi A, B, C/izin operasional), dan lain-lain. Hal-hal inilah yang kemudian memicu munculnya penolakan terhadap pelaksanaan UN.

Bila ditelusuri lebih mendalam akar masalahnya adalah ketidaksiapan sekolah/madrasah untuk melaksanakan UN tersebut. Banyak hal yang melatarbelakangi ketidaksiapan tersebut, mulai dari kemampuan siswa, kompetensi guru, sarana/fasilitas/pembiayaan pendidikan, dan lain-lain. Maka tidaklah mengherankan kalau UN ini telah berpengaruh (effect) dan berdampak (impact) be- 
sar tidak hanya pada praktik pendidikan tapi juga pada kehidupan sosial.

Dalam konteks sistem pendidikan madrasah, pada satu sisi kebijakan ini telah berhasil merubah pandangan masyarakat menjadi semakin positif terhadap madrasah, tetapi pada sisi lain juga menjadikan madrasah semakin terpuruk citranya di mata masyarakat, terutama bila dikaitkan dengan hasil UN. Bagi para pengelola madrasah, kebijakan UN telah memposisikan dan menghadapkan madrasah pada situasi dilematis. Dilema yang dihadapi tersebut lebih disebabkan karena: 1) keterikatan MA dengan konteks historis kelahirannya; dan 2) realitas obyektifnya dengan berbagai kekurangan dan kelemahannya.

Satu hal yang pasti, kebijakan UN telah merubah MA menjadi semakin kehilangan jati diri dan rohnya sebagai madrasah. Indikator tentang hal ini dapat dilihat dari semakin berkurangnya kurikulum/ pengajaran ilmu-ilmu agama Islam, yang berakibat pada minim/rendahnya penguasaan lulusan MA pada bidang tersebut. Atas dasar realitas ini, menurut Drs. Abdullah Zahid, M.Ag. (Kepala MAN 1 Kudus), MA saat ini tidak cocok lagi menyandang predikat sebagai "Madrasah Aliyah" tetapi lebih tepat disebut sebagai "Sekolah Aliyah". ${ }^{18}$

Untuk dapat mencapai standar kelulusan dalam UN, madrasah harus mempersiapkan siswanya dengan cepat, instant dan sangat pragmatis, seperti menambah jam belajar untuk membahas materi $\mathrm{UN}$, menyelenggarakan tryout, mendatangkan guru dari luar sekolah untuk membimbing siswa, dan lain sebagainya. Singkatnya siswa di-drill agar bisa lulus dalam UN tanpa mempertimbangkan kapasitas dan kemampuan siswa.

Secara akademik, hasil drill bukanlah merupakan cermin dari proses pembelajaran yang dilakukan terus menerus dan berkesinambungan yang melibatkan guru, siswa, dan bahkan orang tua siswa. Adanya "intervesi" yang berlebihan terhadap mata pelajaran yang di-UN-kan menyebabkan UN tidak bisa dijadikan tolak ukur evaluasi pembelajaran secara alamiah, karena telah terdistorsi dengan kegiatan-kegiatan pragmatis dan mekanis seperti pembahasan soal-soal yang terDahulu guna mempredisksi soal yang akan datang, tryout, driil, bimbingan belajar, dan lain sebagainya.

\footnotetext{
${ }^{18}$ Hasil wawancara dengan Drs. Abdullah Zahid, M.Ag. (Kepala MAN 1 Kudus) pada tanggal 23 Mei 2010.
} 
Karena tingginya standar kelulusan dan tingkat kesulitan soal UN pada satu sisi, dan berbagai keterbatasan yang ada pada MA pada sisi yang lain, maka muncullah dampak negatif. Praktik kecurangan, manipulasi dan ketidakjujuran seolah menjadi rahasia umum dalam pelaksanaan UN, baik oleh guru maupun siswa, dengan modus yang sangat beragam. Dalam penelusuran penulis terhadap para guru dan kepala madrasah, itu semua terjadi sebagai bentuk empati sosial (social empahatic) dan rasa khawatir terhadap peserta didiknya dalam upaya untuk memepertahankan "nama baik" madrasah, yang dipicu oleh sebuah kebijakan pemerintah yang "anti realitas", sehingga menimbulkan kegelisahan dan keresahan. Sudah menjadi rahasia umum, madrasah sebagai lembaga pendidikan masih mengalami berbagai keterbatasan untuk berlangsungnya proses pembelajaran berkualitas. Dalam kondisi seperti ini guru, siswa dan pihak-pihak terkait akhirnya "berkompromi" dan "bersatu" untuk melawan kebijakan UN tersebut dalam bentuk tindakan-tindakan yang bertentangan dengan akhlakul karimah yang tidak dibenarkan secara hukum, yang penting mendapat predikat lulus dan sebisa mungkin dengan nilai tinggi. "Jalan pintas" dan praktik-praktik tidak terpuji tersebut dianggap "sah dan pantas" demi untuk sebuah predikat "lulus". Yang lebih menarik, upaya-upaya manipulatif dan kompromistik tersebut semakin kreatif dari tahun ke tahun, yang sesungguhnya adalah sebuah proses menuju ke arah demoralisasi anak bangsa. Ini tentu sangat bertentangan dengan jati diri madrasah sebagai sekolah umum berciri khas Islam.

Secara jujur harus diakuai pula bahwa, pelaksanaan UN memang telah memotivasi siswa, guru maupun madrasah utuk meningkatkan proses pembelajaran, namun hal itu tidak seimbang dengan beban sosial dan politis yang mereka tanggung. Siswa akan malu kalau tidak lulus, guru merasa akan malu juga kalu muridnya tidaklulus, dan secara institusional lembaga juga akan malu dan prestisenya akan turun bila muridnya (banyak yang) tidak lulus. Implikasinya, madrasah akan semakin sulit mendapatkan siswa pada tahun ajaran baru karena dianggap sebagai madrasah yang tidak berkualitas. Itu artinya madrasah akan tidak memiliki masa depan alias mati, terutama untuk madrasah swasta karena "nafas kehidupannya" sangat tergantung pada sumbangan pendidikan dari siswa. 
Proses pembelajaran yang bertumpu pada pengejaran angka dan standar kelulusan, tidak menempatkan siswa sebagai subyek tetapi hanya menjadi obyek yang harus menguasai berbagai macam materi UN tanpa mempertimbangkan kapasitas siswa, sangatlah tidak manusiawi. Inilah yang oleh Paulo Freire disebut dengan konsep pendidikan banking concept of education. ${ }^{19}$ Praktik pendidikan seperti ini secara sistematik akan membius dan mematikan kreativitas siswa dengan segala potensi yang dimilikinya. Yang terjadi, siswa menjadi gelisah, stress, frustasi, bahkan depresi karena dihinggapi rasa takut dan malu jika gagal UN. Berdasarkan paparan para guru yang penulis wawancarai secara random, tidak sedikit siswa yang sedih dan menangis setelah keluar dari ruang pelaksanaan UN karena tidak yakin atas jawaban yang mereka kerjakan, padahal menurutnya, dalam satu tahun terakhir ini ribuan soal telah dipelajarinya, namun hanya sedikit sekali yang keluar dalam soal UN. Dalam Istilah Pierre Bourdieu, inilah praktik kekerasan simbolik (symbolic violence) ${ }^{20}$ yang amat berbahaya bagi perkembangan psikologis siswa. Dalam istilah Paulo Freire, praktik ini disebut dengan dehumanisasi (dehumanization) di dunia pendidikan yang bertentangan dengan fitrah manusia yang bebas dari kekangan. ${ }^{21}$ Praktek pendidikan yang demikian ini juga akan berdampak secara psikologis dan mengganggu perkembangan mental anak (mental disorder) dalam mengarungi kehidupan selanjutnya. ${ }^{22}$

Ini artinya praktik pendidikan kita telah terjebak pada logika pelatihan yang mekanistik dan praktis, sehingga menyebabkan involusi pendidikan, yakni peningkatan kualitas pendidikan madrasah bahkan sekolah pada umumnya hanya sebatas artifisial saja belum sampai menyentuh bagian substansial. Bahkan demi UN angka telah menjadi "dewa" yang paling ditakuti oleh siswa, guru, orang tua, bahkan madrasah sebagai lembaga. Yang lebih ironis lagi, ketakutan dan kekhawatiran ini malah justru mendorong praktek-praktek yang tidak jujur di madrasah. Padahal

${ }^{19}$ Paulo Freire. 2000. Pendidikan Kaum Tertindas. (Jakarta: LP3ES), hlm. 55.

${ }^{20}$ Pierre Bourdieu dan Jean Claude Passeron, Reproduction in Education, Society and Culture, (London: Sage Publication, 1990), hlm. 1.

${ }^{21}$ Freire, Pendidikan Kaum Tertindas..., hlm. 19.

${ }^{22}$ Marsana Windhu. Dimensi Kekerasan Tinjauan Teoritis atas Fenomena Kekerasan”. Dalam Franz Magnis Suseno (ed), Melawan Kekerasan Tanpa Kekerasan. (Yogyakarta: Pustaka Pelajar, 2000), hlm.14. 
UN sejatinya merupakan instrumen untuk melaksanakan evalusi mengenai proses pembelajaran yang telah dilakukan oleh guru, siswa, dan orang tua.

Berdasarkan identifikasi peneliti terhadap pelaksanaan UN di MA di Kudus, ada tiga komponen dalam MA yang paling terbebani, yaitu:

1. Guru

Guru merupakan variabel penting dan strategis untuk berlangsungnya proses dan hasil pendidikan berkualitas. Bahkan kehadiran guru yang kompeten dan berkualitas akan mampu mensubstitusi kekurangan yang ada pada komponen pendidikan yang lain. Dalam istilah Dedi Supriyadi, kemajuan Prestasi belajar siswa banyak bergantung pada kepiawaian guru dalam membelajarkan siswa, $^{23}$ serta lingkungan pembelajaran yang mendukung proses belajar mengajar.

Dalam konteks pelaksanaan UN di Madrasah, keberadaan guru dianggap sebagai sosok yang paling bertanggungjawab terhadap keberhasilan siswa dalam UN. Untuk mewujudkan harapan tersebut guru-guru pengampu mata pelajaran yang di-UN-kan, dengan dukungan dari kepemimpinan madrasah, menyelenggarakan/menambah jam pelajaran guna membahas soal-soal yang telah diujikan pada tahun sebelumnya.

Proses ini sesungguhnya hanyalah prediksi dengan harapan soal-soal (sebagian) diujikan kembali. Bila ternyata soal-soal yang telah dipelajari tersebut ternyata tidak keluar dalam UN, maka siswa pun akan kecewa, sedih, menangis, bahkan depresi karena tidak mampu mengerjakan soal UN. Fakta inilah yang membuat para guru menjadi gelisah dan khawatir, sehingga mendorong guru untuk melakukan pengulangan-pengulangan materi pelajaran, bahkan melakukan tindakan yang bertentangan dengan nilai-nilai kependidikan dan akhlakul karimah.

Di samping usaha yang bersifat rasional empiris tersebut, hampir di semua madrasah di kudus juga melakukan usahausaha yang bersifat spiritual yang dilakukan tidak hanya oleh siswa tetapi juga melibatkan guru dan orang tua siswa dengan

${ }^{23}$ Dedi Supriyadi, Mengangkat Citra Guru dan Martabat Guru. (Yogyakarta: Adicita Karya Nusantara, 2000), hlm. 179. 
mengadakan ritual-ritual keagamaan, seperti istigosah, mujahadah secara periodik menjelang UN, membaca wirid, salat ḍuha bersama, ziarah kubur wali, dan melakukan ritual pada tengah malam seperti salat tahajud, membaca tahlil dan manaqib secara berjama'ah. Bahkan di beberapa madrasah, para guru atas perintah pihak madrasah meminta ijazah/do'a khusus kepada para kiai kharismatik dan habib dengan meminum air yang telah didoakan. Semua tradisi keagamaan tersebut, dalam konteks UN telah mengalami disorientasi tujuan karena dijadikan sarana untuk meminta kelulusan dalam UN. Dalam hal ini guru menjadi aktor dan motivator utama. Sebuah fenomena yang sulit dicari penjelasannya secara ilmiah.

Terkait dengan guru dan mata pelajaran yang di-UN-kan, telah terjadi diskriminasi dan kesenjangan di antara guru-guru di madrasah. Hal ini terjadi karena para guru yang mata pelajarannya di-UN-kan, di samping mendapatkan honorarium yang lebih, prentise mereka juga menjadi naik karena menjadi guru yang penting dan berperan dalam UN. Guru yang tidak mengajarkan mata pelajaran yang di-UN-kan tidak memiliki kesempatan untuk menambah jam pelajaran, sehingga tidak memiliki kesempatan untuk mendapatkan honorarium tambahan. Akibatnya, di madrasah terjadi ketegangan internal yang bersifat laten dan menyebabkan hubungan sosial (social relation) di antara guru menjadi kurang harmonis. Hal ini dapat dilihat dari pergunjingan sosial di atara para guru.

2. Siswa Madrasah

Berbeda dengan di sekolah, dari sudut kurikulum siswa madrasah lebih berat bebannya dibanding dengan siswa sekolah. Seperti telah disinggung di atas, mata pelajaran PAI untuk madrasah dijabarkan dalam lima pelajaran dan masih ditambah dengan kurikulum lokal sesuai visi-misi madrasah (swasta). Oleh karenanya, selain mengikuti ujian nasional, dengan jumlah mata pelajaran yang sama seperti yang diujikan kepada siswa SMA, untuk siswa MA harus mengikuti Ujian Akhir Madrasah Berstandar Nasional (UAMBN), berupa mata pelajaran yang tergabung dalam rumpun PAI yang meliputi: Quran-Hadis, Aqidah Akhlak, Fiqh, Sejarah Kebudayaan Islam, Bahasa Arab. Ditambah lagi 
dengan Ujian Madrasah, yang meliputi mata pelajaran agama Islam yang terangkum dalam Kurikulum Lokal.

Dari sudut pembelajaran, mata pelajaran dan jam belajar yang harus diikuti oleh siswa MA lebih banyak dan panjang dibanding dengan anak SMA. Padahal secara faktual mayoritas siswa madrasah pada umumnya berasal dari kalangan menengah ke bawah yang secara ekonomis akan mengalami beberapa kendala untuk mengikuti pembelajaran tambahan. Secara psikologis penambahan jam pelajaran ini akan mengurangi "ruang dan waktu" untuk menikmati dunia anak/remaja untuk "bermain". Kegiatan belajar yang melampaui kapasitas dan kemampuan siswa ini telah berpengaruh negatif bagi kesehatan dan mental siswa. Tidak jarang mereka menjadi sakit dan terganggu fikirannya.

Kegelisahan dan ketidaktenangan siswa secara mental tersebut (atas arahan dan bimbingan guru) diminimalisir dengan melakukan ritual-ritual keagamaan sesuai dengan tradisi keagamaan yang mereka yakini, seperti istigosah, salat ḍha, mujahadah, wirid dan lain sebagainya. Fenomena inilah yang nampak di semua MA dalam menghadapi UN, bahkan tidak hanya di madrasah di SMA (negeri dan swasta) juga melakukan hal yang sama, hanya frekuensi dan intensitasnya yang berbeda. Pendeknya, siswa menjadi kelompok yang paling gelisah dibandingkan dengan kelompok guru maupun kelompok orang tua.

\section{Orang Tua Siswa}

Menjelang dan setelah pelaksanaan UN, orang tua murid juga menjadi pihak yang ikut menanggung beban, Baik beban psikis, ekonomis maupun sosial. Berbagai pikiran atau bahkan kegelisahan muncul setelah mereka mendapat penjelasan dari pihak sekolah melalui "sosialisasi UN" yang memang selalu diadakan oleh pihak madrasah. Semua perhatian dan potensi orang tua siswa kemudian juga dicurahkan untuk keberhasilan anak-anak mereka dalam UN. Orang tua yang mampu secara finansial mendorong anaknya untuk mengikuti bimbingan belajar di luar madrasah. Orang tua, siswa dan lembaga bimbingan belajar disibukkan dengan aktivitas pembelajaran yang menekankan pada repetisi soal-soal ujian. Dari sudut partisipasi masyarakat/orang tua, ini menjadi sinyal positif 
bagi keterlibatan dan sinergitas berbagai komponen pendidikan dalam proses pendidikan.

Kekhawatiran dan kegelisahan yang dirasakan oleh orang tua siswa terkadang juga berakibat pada pemaksaanpemanksaan terhadap anak-anak mereka untuk terus belajar demi menghadapi UN. Mereka juga ketakutan bila anaknya tidak lulus di ujian akhir yang mereka ikuti. Untuk melengkapi usaha rasional zahiriyah tersebut para orang tidak jarang juga melakukan usaha spiritual dalam bentuk ritualritual keagamaan tertentu, melaksanakan puasa senin-kamis dan tradisi selamatan. Bahkan pelaksanaan UN telah mampu "mengintegrasikan" upaya-upaya rasional dengan upaya spiritual. Di satu sisi upaya spiritual ini mampu memberikan pencerahan dan peningkatan keimanan seseorang, namun di sisi lain, hal ini juga dapat melemahkan usaha rasional yang dilakukan. Hal ini terjadi karena mereka beranggapan bahwa semua ini sudah ditakdirkan dan diatur oleh Allah swt. Praktik pendidikan dan ritual keagamaan, menurut William A. Smith,seharusnya didasarkan pada kesadaran individualdan panggilan hati nurani seseorang dan bukan didasarkan pada situasi dan kondisi terpaksa, karena kesadaran merupakan proses dialogis dalam diri seseorang dalam upaya memecahkan masalah yang dihadapi secara bersama-sama. ${ }^{24}$

Berbagai fenomena yang muncul sebagai respons atas kebijakan UN yang terwujud dalam sebuah kesadaran, merujuk pada pendapat Mansour Fakih, ${ }^{25}$ dapat dikelompokkan menjadai tiga kesadaran, yaitu: 1) kesadaran magis, yang mengandalkan aspek kekuasaan supranatural/kuasa prima (taqdir) dalam memandang suatu masalah; 2) kesadaran naif, yang memandang aspek manusia yang menjadi penyebab masalah yang muncul dalam masyarakat; dan 3) kesadaran kritis, yang melihat sistem dan struktur sebagai penyebab problematika yang muncul di masyarakat.

Kegelisahan orang tua yang diiringi dengan peningkatan kesadaran meningkatkan partisipasi masyarakat dalam pendidikan merupakan bentuk penguatan sosial untuk

${ }^{24}$ William A. Smith, Conscientizacao: Tujuan Pendidikan Paulo Freire. (Yogyakarta: Pustaka Pelajar, 2001), hlm.4.

${ }^{25}$ Mansour Fakih, dkk, Pendidikan Populer: Membangun Kesadaran Kritis, (Yogyakarta: Insist, 2001), hlm. 18-23. 
transformasi praksis pendidikan. Munculnya aspek religious dalam partisipasi masyarakat mempunyai dampak positif terhadap pengembangan spiritual seseorang, meskipun dalam keadaan terpaksa. Hampir tidak ada jalan keluar dan jawaban pasti untuk menghadapi UN, baik guru, siswa, maupun orang tua, mereka menambatkan segala keinginannya kepada kekuatan supranatural, meski hanya bersifat temporer, karena usaha yang dilakukan telah menguras seluruh potensi yang tidak jarang berimbas pada melemahnya aspek psikologis dan fisik anak.

\section{Probleatika UN di Madrasah}

Di samping tiga kelompok yang paling terbebani dengan pelaksanaan UN, berdasarkan data hasil penelusuran penulis pada 29 MA di Kudus, berikut ini dipaparkan beberapa pengaruh dan dampaknya yang timbul dari pelaksanaan UN di MA. Pengaruh tersebut terutama yang berkaitan dengan praktik dan sistem pembelajaran di MA.

1. Standar Kelulusan.

Standarisasi adalah keniscayaan untuk mencapai dan mengetahui kualitas proses dan hasil pendidikan. Kualitas pendidikan tidak mungkin bisa dicapai tanpa diawali dengan penentuan standar, baik input, proses maupun output-nya. Dalam konteks pelaksanaan UN, penentuan skor standar kelulusan memang menjadi suatu keniscayaan, tapi persoalannya Apakah skor standar kelulusan tersebut sudah didasarkan atas realitas heterogenitas yang melekat pada lembaga pendidikan kita.

Belum lagi persoalan mata pelajaran yang diujikan hanya enam mata pelajaran dari sekian banyak mata pelajaran yang diterima peserta didik dalam proses pendidikan dan pengajaran di MA. Terlebih bila enam mata pelajaran itu kemudian dijadikan penentu, atau setidaknya variabel utama untuk menentukan kelulusan siswa. Di sinilah kemudian muncul pertanyaan, adilkah atau tepatkah standarisasi proses dan hasil pendidikan MA hanya diukur dengan enam mata pelajaran, sementara dalam statusnya sebagai sekolah menengah umum berciri khas agama Islam banyak mata pelajaran tambahan yang diberikan. 
Fakta inilah yang kemudian berdampak negatif pada persepsi dan perilaku siswa dan guru MA. Para siswa menjadi cemas, para guru menjadi kurang percaya diri dan para pengelola manajemen MA menjadi terbayang dengan cerita dan gambaran buruk akan masa depan madrasahnya. Banyak pihak, terutama guru dan siswa menilai meskipun standar yang dipatok masih jauh dari negara-negara maju, tetapi tetap saja mereka khawatir akan kemungkinan tidak lulus dalam UN.

Standar kelulusan yang dipatok dari tahun ke tahun terus naik (untuk tahun 2008 minimal rata-rata 5,25), bagi MA sesungguhnya terlalu tinggi dan berat, terutama untuk sebagian besar MA swasta. Karena terlalu beratnya standar tersebut, maka harapan para pengelola MA dan para guru hanya sebatas yang penting lulus, berapa nilai yang diperoleh menjadi tidak penting. Untuk sekedar menyebut contoh betapa beratnya UN ini bagi MA, seperti yang dikatakan oleh Bapak Ali Muchtadi, S.Ag. (Kepala MA Nurussalam Besito: 17/4/2008), kelulusan dalam UN bagi siswa MA merupakan anugerah yang luar biasa dari Allah) ${ }^{26}$.

Hal itu terjadi karena banyaknya kendala yang dihadapi oleh MA dalam meningkatkan kualitas proses dan hasil pembelajaran, antara lain karena; a) input siswa yang kurang bagus; b) keterbatasan dana bahkan cenderung kurang; c) ada atau bahkan banyaknya guru yang miss-match; d) banyaknya mata pelajaran yang harus diterima oleh siswa. Tidak jauh berbeda dengan para guru, seperti yang dirasakan oleh Khofiyanida Afriani (siswa MA NU Banat kelas XII IPA) ${ }^{27}$, bagi dia dan teman-temannya standar nilai UN yang ditetapkan oleh pemerintah menurutnya terlalu tinggi sehingga menimbulkan kecemasan bagi dia dan teman-teman.

26 Untuk sekedar menyebut contoh betapa beratnya UN bagi MA swasta kecil, pada pelaksanaan UN tahun 2008; di MA Nurussalam dari peserta ujian 86 yang tidak lulus 6 siswa; MA Matholiul Huda dari peserta ujian 19 orang yang tidak lulus 8 siswa; MA Miftahut Tholibin Mejobo angka ketidaklulusan mencapai $60 \%$.

${ }^{27}$ MA NU Banat Kudus adalah termasuk kategori MA swasta terbaik di Kabupaten Kudus, bahkan pada tingkat nasional MA ini pernah mendapat predikat MA harapan terbaik I se-Indonesia. 
2. Terjadinya disorientasi sistem pendidikan dan pembelajaran

Sebelum tahun 2008 mata pelajaran yang diujikan dalam UN hanya tiga mata pelajaran dan mulai tahun 2008 mata pelajaran yang diujikan menjadi enam mata pelajaran, yaitu: a) Jurusan IPA; Matematika, Bahasa Indonesia, Bahasa Inggris, Fisika, Kimia, dan Biologi. b) Jurusan IPS; Matematika, Bahasa Indonesia, Bahasa Inggris Ekonomi, Geografi, dan Sosiologi. c) Jurusan Bahasa; Matematika, Bahasa Indonesia, Bahasa Inggris, Sastra Indonesia, Bahasa Asing lain, dan Antropologi/Sejarah Budaya. Khusus untuk MA ada satu jurusan lagi, yaitu Jurusan Keagamaan (MAKMadrasah Aliyah Keagamaan) mata pelajaran yang diujikan; Matematika, Bahasa Indonesia, Bahasa Inggris, Bahasa Arab, dan Qur'an-Hadis. Penetapan enam mata pelajaran yang diujikan, dari sekian banyak mata pelajaran yang diajarkan di MA inilah yang kemudian berpengaruh besar terhadap kinerja MA dan persepsi siswa terhadap mata pelajaran lain yang tidak diujikan. Pada kenyataannya target dan ukuran kinerja MA hanya fokus pada upaya bagaimana agar persentase angka kelulusan menjadi maksimal atau setidaknya tinggi. Tingkat kelulusan 100\% menjadi ukuran kinerja dan Prestasi suatu MA, sehingga tujuan pendidikan dan pengajaran di MA menjadi tereduksi hanya demi untuk kelulusan UN.

Dengan ukuran seperti ini, maka tidak jarang model pembelajaran dan durasi pembelajaran selalu dihubungkan dengan seberapa besar kontribusinya terhadap kesiapan dan kemampuan siswa untuk mengerjakan soal UN. Yang terjadi makna dan hakikat pendidikan kemudian tereduksi seolah hanya pada kemampuan (kognitif) menjawab soal. Kebermaknaan sebuah proses pendidikan hanyalah sebatas lulus UN dan mendapat ijazah. Internalisasi nilai sebagai tingkatan dan sekuensi penting dalam proses pembelajaran menjadi hilang, karena semua waktu dan usaha difokuskan pada "keterampilan" siswa dalam memahami dan menjawab soal.

Penentuan dan pembatasan mata pelajaran yang akan diujikan dalam UN berdampak pada fokus proses pembelajaran di madrasah yang hanya ditekankan pada penguasaan mata pelajaran tersebut, sedangkan mata pelajaran lain menjadi terabaikan dan seolah menjadi kurang penting. 
Padahal bila melihat tujuan pendidikan di MA mata pelajaran tambahan (PAI) itulah sesungguhnya yang menjadi jati diri dan Karakter esensialnya. Ekses lain adalah terjadinya diskriminasi dan pengabaian terhadap guru dan mata pelajaran lain yang tidak diujikan. Para siswa, guru dan bahkan orang tua lebih memusatkan perhatiannya terhadap mata pelajaran yang akan diujikan dengan berbagai upaya, termasuk berbagai usaha yang bertentangan dengan nilai-nilai fundamental pendidikan.

Melihat gejala tersebut dan dalam rangka untuk menguatkan posisi mata pelajaran PAI dan berbagai mata pelajaran tambahan sesuai visi ke-madrasah-an, beberapa MA swasta yang masuk kategori sedang dan besar membuat kebijakan pengaman. Semua MA swasta di Kudus memberlakukan kebijakan ujian lokal madrasah dengan mengujikan semua mata pelajaran agama Islam yang masuk kategori muatan lokal, dengan mendapatkan ijazah (syahadah) tersendiri.

Bagi MA swasta besar, di samping UN semua siswa diwajibkan lulus ujian madrasah dan kelulusan pada ujian madrasah ini menjadi syarat pengambilan ijazah nasional. Langkah ini, seperti diakui dan dijelaskan oleh para kepala MA cukup efektif untuk meningkatkan motivasi dan minat para siswa untuk tetap serius dan tidak memandang remeh terhadap berbagai mata pelajaran PAI dan mata pelajaran tambahannya.

Hal lain yang muncul dengan adanya kebijakan UN adalah terjadi disorientasi pada arah dan tujuan pembelajaran di MA. Karena sistem dan model UN cenderung hanya mengukur aspek kognitif, maka pembelajaran di kelas cenderung hanya mengolah ranah kognitif, padahal ranah afektif yang sesungguhnya menjadi ranah yang paling penting dalam pembentukan Karakter dan kepribadian peserta didik sebagai muslim yang berakhlak mulia menjadi terabaikan, atau setidaknya kurang mendapatkan porsi yang memadai.

Hal ini dapat dilihat dari berbagai kebijakan sebagian besar MA swasta dalam mempersiapkan siswanya untuk mengikuti UN. Ada beberapa MA yang mengasramakan siswanya selama 1 s/d 2 Minggu untuk "pendalaman" materi UN. Ada MA yang dalam tiga bulan atau satu semester 
menjelang UN tidak mengajarkan mata pelajaran lain kecuali mata pelajaran yang diujikan. Dalam praktiknya dua kegiatan tersebut lebih difokuskan pada latihan mengerjakan atau menjawab contoh-contoh soal UN. Yang lebih memprihatinkan lagi pada setiap akan dilaksanakan UN selalu dibentuk "tim sukses UN", yang dalam banyak hal berkonotasi negatif.

3. Proses pembelajaran yang kurang bermakna

Untuk mempersiapkan para siswanya menghadapi dan mengerjakan soal-soal UN, para guru biasanya menggunakan metode pembelajaran driil, di mana para siswa dilatih untuk mengerjakan sejumlah soal yang diprediksi akan keluar dalam ujian. Melalui metode ini guru mengharapkan para siswa terbiasa menghadapi soal ujian, dan menguasai berbagai teknik dan trik mengerjakan soal yang akan dihadapi. Pembelajaran dengan metode ini sesungguhnya tidak sesuai dengan tujuan pendidikan yang antara lain adalah transfer of values atau internalisasi nilai. Pada ranah kognitif model pembelajaran seperti ini kurang mampu mengembangkan kemampuan berpikir pada tingkatan memecahkan masalah (problem solving), yang sesungguhnya merupakan indikator pencapaian kecerdasan kognitif yang tinggi, sebagaimana diharapkan dalam pencapaian tujuan pembelajaran.

Bila melihat tujuan pendidikan MA, maka tujuan pembelajaran yang lebih penting bahkan menjadi tujuan akhir dari semua proses adalah pembentukan pribadi dan Karakter peserta didik sesuai dengan norma dan ajaran Islam. Tujuan tersebut hanya bisa dicapai manakala sistem dan model pembelajarannya memungkinkan peserta didik untuk bisa memahami dan menghayati. Selanjutnya mengamalkan dalam kehidupan sehari-hari segala apa yang telah mereka ketahui.

Hanya dengan tingkatan seperti ini pembelajaran akan memiliki makna, bila tidak maka pembelajaran hanya sebatas pemberian dan diperolehnya informasi/pengetahuan tanpa memiliki pengaruh dan makna bagi pengembangan diri peserta didik secara menyeluruh dan utuh.

\section{Relevan UN dengan kompetensi lulusan MA}

Sebagai lembaga pendidikan yang merupakan modernisasi sistem pesantren, MA tidak bisa lepas dari nilai dan atribut ke-Islaman. Dalam konteks UN, maka MA menjadi 
pihak yang merasa diperlakukan tidak fair (unfair treatment), terutama terkait dengan tujuan spesifik dan mata pelajaran yang diujikan.

Dengan hanya enam mata pelajaran yang diujikan, dan semua mata pelajaran Agama Islam baik yang terangkum dalam rumpun PAI maupun mata pelajaran tambahan/pengayaan tidak ada yang diujikan, maka dari sisi tujuan aspek pokok dari tujuan MA menjadi tidak terukur dan terevaluasi. Padahal mata pelajaran PAI ini sesungguhnya merupakan materi inti (core) pembelajaran dalam rangka untuk mencapai tujuan tersebut dan sekaligus menjadi ciri pembeda dengan sekolah umum.

Seperti diakui oleh para pengelola dan guru MA, UN di mata para guru dan siswa dipahami sebagai tujuan akhir dengan kelulusan menjadi indikator keberhasilannya. Guru dianggap sukses dan berkinerja bagus manakala berhasil membawa siswanya menuju kelulusan, dan akan divonis telah gagal menjalankan tugas manakala banyak siswanya yang tidak lulus.

Itulah sebabnya, mayoritas guru merasa berat manakala mendapat tugas/ditawari untuk mengajar di kelas XII atau kelas XI. Mereka merasa lebih nyaman dan tanpa beban jika mengajar di kelas X dan XI. Guru yang mengajar di kelas XII seringkali menghadapi berbagai ketegangan karena beban psikologis, terutama saat-saat mendekati dilaksanakannya UN. Hal ini terjadi pada hampir semua MA swasta, terutama untuk MA swasta kecil yang ada di pinggiran kota. Untuk MA besar/maju, seperti MA negeri dan beberapa MA swasta besar semisal MA NU Banat Kudus, keadaannya mungkin tidak seekstrem itu, karena para siswanya relatif lebih siap dalam menghadapi UN. Di samping para siswanya lebih siap karena input-nya relatif bagus juga didukung oleh kompetensi dan komitmen guru dan berbagai fasilitas yang dimilikinya relatif cukup dan bagus.

Tidak seperti MA swasta kecil pada umumnya, pada MA besar persiapan untuk menghadapi UN tidak ada upaya berlebihan karena pengondisian terhadap siswa dan guru sudah dipersiapkan sejak awal. Seperti dikatakan oleh Bapak Moh. Said (Kepala MA NU Banat Kudus: 14/5/2008), "Saya sangat setuju dengan adanya UN seperti yang telah 
dilaksanakan selama ini yang bertujuan untuk meningkatkan kualitas pendidikan, akan tetapi seharusnya tidak hanya mata pelajaran tertentu saja yang diujikan, tapi juga termasuk mata pelajaran agama (PAI) harus juga diujikan supaya tidak ada diskriminasi terhadap mata pelajaran".

Dengan diujikannya PAI dalam UN, maka perhatian para siswa terhadap pelajaran tersebut menjadi lebih serius dan lebih bermakna, seperti sebelum dilaksanakan UN. Seperti diakui oleh ibu Eti Muznah (Waka Kurikulum MA Nahdhatul Muslimin Undaan Kidul: 27-28/03/2008), sejak dilaksanakannya UN kemampuan pengetahuan agama Islam siswanya menjadi turun drastis. Sebagai contoh beliau merujuk pada kemampuan Bahasa Arab (dan ilmu-ilmu alat lainnya) para siswa menjadi sangat turun sejak diberlakukannya kebijakan UN.

Penyebabnya tiada lain karena konsentrasi para pengelola MA, guru dan siswa hanya tertuju pada mata pelajaran yang diujikan dalam UN. Secara teknis tidak cukup waktu untuk pembelajaran bidang agama Islam tersebut, bahkan hampir semua waktu dan tenaga tercurahkan untuk persiapan pelaksanaan UN. Apa yang dikatakan oleh ibu Eti Muznah ini juga diakui dan dirasakan oleh para guru dan pengelola MA di Kudus pada umumnya.

\section{Penutup}

Kebijakan UN bagi madrasah sesungguhnya membanggakan dan memberi harapan, tetapi sekaligus juga memberatkan. Membanggakan karena dengan UN ini lembaga pendidikan madrasah benar-benar diakui sama dengan sekolah. Memberatkan dan menjadi beban karena mayoritas MA sesungguhnya tidak siap, karena sulitnya soal-soal UN untuk dikerjakan siswa MA. Hal ini terjadi karena proses pembelajaran di sebagian besar MA (terutama swasta) masih menghadapi berbagai kendala dan keterbatasan mulai sarana/prasarana, sumber daya manusia, dan visimisi madrasah.

Di samping harus mengikuti UN, siswa MA juga harus mengikuti UAMBN yang diselenggarakan secara nasional dan sentral dari Kementerian Agama Pusat dengan lima mata pelajaran yang terangkum dalam rumpun PAI. Di samping itu untuk siswa MA swasta masih harus mengikuti Ujian Madrasah yang terdiri dari 
mata pelajaran ilmu-ilmu agama Islam sesuai visi-misi madrasah. Fakta inilah yang menjadikan siswa madrasah menjadi terlalu banyak beban, karena banyaknya mata pelajaran yang harus mereka terima dan semuanya diujikan. Dalam konteks seperti ini maka menjadi tidak adil kiranya bila parameter pengukuran antara sekolah dan madrasah disamakan.

Pelaksanaan UN dengan mengujikan hanya enam mata pelajaran telah menyebabkan diskrimanisai antara mata pelajaran yang diujikan dengan yang tidak diujikan. Mata pelajaran yang diujikan menjadi mata pelajaran yang penting dan yang tidak diujikan menjadi tidak atau kurang penting, demikian halnya dengan gurunya. Diskriminasi tersebut berimbas juga pada ketegangan dan konflik yang bersifat laten antara guru pengampu mata pelajaran yang diujikan dengan yang tidak diujikan.

Karena tingginya standar kelulusan dan sulitnya soal-soal UN maka muncullah kekhawatiran di kalangan guru, siswa, orang tua siswa, dan pihak madrasah tentang kemungkinan ketidak lulusan dalam ujian tersebut. Kekhawatiran ini kemudian mendorong mereka untuk melakukan berbagai upaya mulai dari yang empirik rasional sampai yang bersifat supranatural-ruhaniyah. Bahkan sampai pada usaha-usaha yang bertentangan dengan spirit, nilainilai kependidikan,ahlakul karimah dan melanggar terhadap hukum.

Meskipun tujuan kebijakan UN ini adalah baik dalam rangka untuk mengevaluasi proses dan hasil pendidikan, namun karena berbagai penyimpangan yang terjadi di lapangan kebijakan ini menjadi tidak sesuai dengan harapan dan tujuan. Bahkan kabijakan ini telah menyimpang jauh dari tujuan semula, karena telah menjadi komoditas politik bagi pimpinan madrasah dan pimpinan lokal/daerah. Hal ini terjadi karena hasil UN (prosentase kelulusan) menjadi indikator kinerja guru, kepala sekolah/madrasah, dan pimpinan/birokrat di daerah, sehingga mereka ini berkompromi dan bersepakat dengan berbagai cara untuk "mensukseskan UN" dengan membentuk "tim sukses".

\section{Kepustakaan}

Anderson, J.E, Public policy-making. New York: Holt, Rinehart and Winston, 1979. 
Arifin, A., Memahami paradigma baru pendidikan nasional.Jakarta: Ditjen Bagais, 2003.

Azra, Azyumardi, Surau: Pendidikan Islam tradisional dalam transisi dan modernisasi. Jakarta: Logos, 2003.

Burhanudin, J. \& Dina A., Mencetak Muslim Modern: Peta Pendidikan Islam Indonesia. Jakarta: Raja Grafindo Persada. 2006.

Considene, M, Public policy: A critical approach.South Melbourne: Mc Millan Educatio Australia, 1996.

Davis, N.K., Warhurst, J.W.J., \& Waller, Public policy in Australia ( $2^{\text {nd }}$ ed.), NSW Australia: Allen \& Unwin. 1993.

Depertemen Agama RI, Panduan kurikulum 1994 Madrasah. Jakarta: Depag RI, 2004.

Dimyati \& Mudjiono, Belajar dan Pembelajaran, Jakarta: Departemen Pendidikan Nasional berkerja sama dengan Rineka Cipta, 2006.

Dye, T.R., Understanding public policy ( $7^{\text {th }}$ ed.), Englewood Cliffs-New Jersy: Prentice Hall, 1981.

Easton, D., The Political System, New York: Knopf, 1953.

Fernades, H.J.X., Evaluation of Educational Programs, Jakarta: Nasional Educational Planning, Evaluation and Curriculum Development, 1984.

Fullan, M. G., The New Meaning of Educational Change, England: Cassell Educational Limited, 1991.

Harrington, H. J., The improvement process: How America's leading company improve quality, New York: Mc Graw-Hill Book Company, 1987.

Hanuzek, E.A., Education production function, dalam George Psacharopoulos. Econmics of education: Research and studies, London: Oxford; Pergamon Press, 1987.

Hopkins, D., Every School a Great School: Realizing the Potential of System Leadership, New York: Mc Graw Hill-Open University Press, 2006.

Imron, Ali., Kebijakan pendidikan di Indonesia: Proses produk dan masa depannya, Jakarta: Bumi Aksara, 1996.

MacKinnon, F., The Politics of Education: A Study of Political Administration of the Public Schools, Canada: University of Toronto Press, 1960. 
Maksum, Madrasah: Sejarah dan perkembangannya, Jakarta: Logos, 1999.

Mardapi, Djemari, Survey Kegiatan Guru dalam Melakukan Penilaian, Jakarta: Ditjen Dikdasmen Depdikbud, 1999.

Peraturan pemerintahan tentang pelaksanaan undang-undang nomor 2 tahun 1989 tentang sistem pendidikan nasional, Jakarta: Armas Duta Jaya, 1990.

Posavac, E. J. \& Carey, R.G., Program evaluation: Methods and case studies. Englewood Cliffs, New Jersey, Prentice-Hall, 1980.

Prunty, J.J., A critical reformation of educational policy analysis, Victoria: Deakin University Printery, 1984.

Richardson, J. J. (Ed.), Pressure groups. New York: Oxford University, 1993.

Seidman, E., Handbook of Social Intervention, Beverly Hill/London/ New Delhi: Sage Publication, 1983.

Sudjana, Nana, Penilaian Hasil Proses Belajar Mengajar, Bandung: Remaja Rosdakarya, 1989.

Sudjana, N., Penilaian hasil proses belajar mengajar. Bandung: Remaja Rosdakarya, 1995.

Suwito \& Fauzan, (Ed.), Perkembangan Pendidikan Islam di Nusantara: Studi Perkembangan Sejarah dari Abad 20 M, Bandung, Angkasa, 2004.

Taylor, S., Educational Policy and the Politics of Change, London: Routledge, 1997.

Undang-Undang Republik Indonesia Nomor 2 Tahun 1989. Sistem pendidikan nasional, Jakarta: Eko Jaya.

Undang-Undang RI Nomor 20 Tahun2003tentang Sistem pendidikan nasional.

Undang-Undang RI Nomor 2 Tahun 1989 tentang sistem pendidikan nasional.

Undang-Undang RI Nomor 5 Tahun 1974 tentang Pemerintah Daerah.

Undang-Undang Republik Indonesia Nomor. 20 Tahun 2003. Tentang Sistem Pendidikan Nasional

Zuhairini, Sejarah Pendidikan Islam, Jakarta: Bumi Aksara Bekerja sama dengan Dirjen Bagais Departeme Agama RI, 2004. 